nia związane z cyberbiblioterapią, czyli zastosowaniem komputera $\mathrm{w}$ terapii poprzez książkę. Zwraca uwagę, że technologia informacyjna, obejmująca swoim zakresem komputery, oprogramowanie oraz komunikowanie się w sieciach lokalnych i rozległych, wywiera dzisiaj wpływ na niemal wszystkie aspekty życia ludzkiego. Zauważa, że komputer, jako narzędzie poznawcze, może wspierać działania podejmowane również $\mathrm{w}$ ramach biblioterapii, a zajęcia z wykorzystaniem technologii informacyjnej mogą stać się podstawą społecznie pożytecznych działań. Wśród aspektów edukacyjnych technologii informacyjnej wymienia wzbogacenie sposobów i możliwości zdobywania wiedzy i umiejętności, ułatwienie porządkowania i wykorzystywania informacji pochodzących $\mathrm{z}$ różnych źródeł oraz wspomaganie pracy twórczej. Ważna jest również wychowawcza i terapeutyczna funkcja, którą spełnia ta dziedzina. Technologia informacyjna kształci umiejętność poro- zumiewania się i współpracy w grupie, może być wykorzystana do budowania więzi międzyludzkich. Zdaniem autorki biblioteka wyposażona w komputery może stać się miejscem, w którym proces terapeutyczny będzie kontynuowany $\mathrm{w}$ ramach współpracy $\mathrm{z}$ instytucjami powołanymi do leczniczego oddziaływania na psychikę.

Publikacja Od książki dawnej do biblioteki wirtualnej stanowi prezentację interesujących artykułów, które przedstawiają dorobek naukowy poszczególnych ośrodków bibliologicznych w całej Polsce. Dzięki niej możliwe jest poznanie tradycji badań bibliologicznych i zapoznanie się z nowymi obszarami zainteresowań poszczególnych badaczy. Działania te są konieczne do dalszego rozwoju tej dziedziny.

\section{Beata Rygiel}

Instytut Bibliotekoznawstwa i Dziennikarstwa Uniwersytetu Humanistyczno-Przyrodniczego Jana Kochanowskiego w Kielcach
G ażyna Gzella należy do znanych i cenionych badaczy polskich periodyków wydawanych na obszarze zaboru pruskiego, w tym głównie prasy grudziądzkiej. Specyfika i odrębność jej warsztatu polega na wnikliwej analizie funkcjonowania konkretnych tytułów lub ich zespołów w systemie pruskiej cenzury. Systemie bardzo uciążliwym dla, będącej w sferze jego działania, prasy, co wielokrotnie już w licznych publikacjach naukowych badaczka udowodniła. Należy podzi-

\section{Grażyna Gzella, Procesy prasowe redaktorów "Gazety Grudziądzkiej" w latach 1894-1914, Toruń: Wydawnictwo Naukowe Uniwersytetu Mikołaja Kopernika 2010, 248 s., ISBN 987-83-231-2475-7}

wiać za każdym razem jej rzetelność i skrupulatność w dążeniu do jak najpełniejszej rekonstrukcji zmagań pol- 
skich wydawców i redaktorów z pruskimi sędziami, prokuratorami oraz policją.

W ostatniej książce Procesy prasowe redaktorów „Gazety Grudziądzkiej” w latach 1894-1914 (Toruń 2010) Grażyna Gzella zawęziła obszar badań do tytułowego periodyku. Wydawać się może, że o „Gazecie Grudziądzkiej” i jej twórcy Wiktorze Kulerskim wiemy bardzo dużo, potwierdza to przywołana w przypisach oraz zamieszczona w formie bibliografii załącznikowej literatura przedmiotu. Okazuje się jednak, iż autorce udało się do obiegu naukowego wprowadzić wiele nieznanych dotąd ustaleń, zaprezentować nowe źródła. Weryfikuje ona bowiem niektóre opinie, udowadniając tym samym, że problem cenzury można rozpatrywać na wiele sposobów. Sama zaś bardzo wyraźnie zaznacza, że „celem rozprawy jest w miarę wszechstronne omówienie działań sądownictwa pruskiego dążącego do ograniczenia wolności słowa na przykładzie periodyku Kulerskiego, ujawnienie mechanizmów wykorzystywanych w tłumieniu rozwoju prasy, a także ukazanie odważnej postawy dziennikarzy polskich piętnujących zapędy germanizatorskie, broniących obecności języka polskiego w życiu codziennym, kształtujących świadomość narodową i społeczną" (s. 11). Zamiar bardzo ambitny, lecz - co należy podkreślić - zrealizowany z powodzeniem, jak przystało na doświadczoną specjalistkę w tym zakresie.

Recenzowana praca składa się z sześciu rozdziałów, poprzedzonych interesującym, rzeczowym i merytorycznym wstępem, wprowadzającym czytelnika w przyjętą przez autorkę rozprawy strategię badawczą. W rozdziale pierwszym zatytułowanym $\mathrm{Wa}$ runki powstania i funkcjonowania „Gazety Grudziądzkiej” została przedstawiona sylwetka miasta Grudziądza z końca XIX i początku XX w., omówiono obowiązujące prawo prasowe oraz strukturę sądownictwa. Badaczka przybliżyła również warunki i etapy rozwoju firmy wydawniczo-drukarsko-prasowej Wiktora Kulerskiego, który doskonale rozumiał ogromne potrzeby w zakresie prasy polskiej na obszarze Prus Zachodnich. W rozdziale drugim Redaktorzy "Gazety Grudziądzkiej” w latach 1894-1914 zostały naszkicowane portrety redaktorów i współpracowników, najpierw oczywiście głównego bohatera, W. Kulerskiego, następnie poznajemy „tajemniczą” Bronisławę ze Świniarskich Rabbowową, Jana Michała Rakowskiego, Walerego i Józefa Rutkowskich, Leona Zielińskiego, Michała Majerskiego, Stanisława Rożanowicza. W sumie 25 biogramów, w kilku przypadkach rekonstruowanych mozolnie $\mathrm{z}$ różnorodnych i rozproszonych źródeł. Warto zaznaczyć, że spośród dwudziestu redaktorów odpowiedzialnych, piętnastu na wniosek prokuratora trafiło „przed oblicze wysokiego sądu”. Sama zaś redakcja „Gazety Grudziądzkiej” miała łącznie 93 potwierdzone $\mathrm{w}$ trakcie badań procesy prasowe oraz trzy wynikające z liczbowania redakcji, o których jednak, jak autorka informuje, nie udało się odnaleźć żadnych informacji. 
Zasadniczym trzonem rozprawy są rozdziały od trzeciego do szóstego, poświęcone kolejnym procesom prasowym redaktorów „Gazety Grudziądzkiej". Podstawę klasyfikacji zgromadzonego w nich materiału badawczego stanowią odpowiednie paragrafy pruskiego kodeksu karnego z 15 maja $1871 \mathrm{r}$. oraz „Ustawy prasowej" z 7 maja 1874 r. (weszła w życie 1 lipca). Opierając się na tym założeniu, z identyczną precyzją analizuje zagadnienia ujęte $\mathrm{w}$ formie tytułów kolejnych rozdziałów: Obraza osób i instytucji (§§ 185, 186, 187) (rozdz. III), Podburzanie do nieposłuszeństwa i gwałtów (§§ 110, 130, 131) (rozdz. IV), Gumowy § 360 (publiczna swawola) (rozdz. V), Karalne wymuszania i loterie (§§ 240,286) oraz występki przeciw prawu prasowemu (rozdz. VI).

Takie działania systematyzujące wydają się w pełni zasadne, gdyż pozwalają z jednej strony poznać sposoby, którymi władza chciała zapewnić sobie właściwy nadzór nad prasą, głównie $\mathrm{w}$ zakresie reglamentacji słowa, z drugiej zaś wskazują środki prawne stosowane w tych celach. Mocną stroną rozważań jest osadzanie głównego obiektu badań w realiach funkcjonowania pruskiego systemu prasowego. Książka skłania więc do szerszego spojrzenia na losy „ludzi prasy”, egzystujących w warunkach niewoli narodowej. Z aprobatą należy również od- nieść się do sposobów dokumentowania prezentowanych w poszczególnych częściach pracy opinii i sądów.

Całość zamyka bardzo interesujące zakończenie, będące podsumowaniem omawianych procesów prasowych redaktorów odpowiedzialnych „Gazety Grudziądzkiej” i równocześnie ich dopełnieniem w formie statystycznych analiz. Autorka skoncentrowała się głównie na ustaleniu liczby wytoczonych redaktorom procesów oraz wskazaniu paragrafów, na podstawie których najczęściej przeprowadzano konfiskaty. Ponadto wśród aneksów znalazł się także wykaz znanych procesów z lat 1894-1914, obejmujący ich daty, nazwiska oskarżonych, treść prokuratorskich orzeczeń z podaniem inkryminowanych tekstów i zasądzone wyroki.

Do rąk czytelników dotarła książka napisana $\mathrm{z}$ dużym znawstwem tematu, piękną polszczyzną, doskonale opracowana edytorsko, odpowiadająca wysokim kryteriom stawianym tego rodzaju rozprawom. Spotka się ona zapewne z dużym uznaniem historyków, prasoznawców, kulturoznawców i regionalistów.

\section{Grażyna Wrona}

Instytut Informacji Naukowej i Bibliotekoznawstwa Uniwersytetu Pedagogicznego im. Komisji Edukacji Narodowej $w$ Krakowie 